\title{
Religion and violence: Shutup Shylock!
}

Author:
Jaco Beyers ${ }^{1}$
Affiliation:
'Department of Science of
Religion and Missiology,
Faculty of Theology and
Religion, University of
Pretoria, South Africa
Research Project
Registration:
Project Leader: J. Beyers
Project Number: 02440237
Description:
This research is part of the
research project, 'Religion,
Theology and Education',
directed by Prof. Dr Jaco
Beyers, Programme Manager:
Biblical and Religious Studies
and member of the
Department of Science of
Religion and Missiology,
Faculty of Theology and
Religion, University of
Pretoria.
Read online:
Corresponding author:
Jaco Beyers,
jaco.beyers @up.ac.za
Dates:
Received: 22 June 2018
Accepted: 30 July 2018
Published: 20 Nov. 2018
How to cite this article:
Beyers, J., 2018, 'Religion and
violence: Shutup Shylock!',
HTS Teologiese Studies/
Theological Studies $74(3)$,
a5165. https://doi.
org/10.4102/hts.v74i3.5165
Copyright:
Cicensee: AOSIS. This work
is licensed under the
Creative Commons

Attribution License.

Violence is not only because of religious differences. Violence is part of human nature. While expressing and living a unique identity, people may experience animosity from 'the other' in society. The natural human response upon infliction is retaliation. To this effect, the play of William Shakespeare, The Merchant of Venice, is taken as an example of conflict in society because of social, financial and religious differences. From the plot in the play, it is deduced that violent actions beget violent responses. The Dutch philosopher, Hans Achterhuis, provides valuable information so as to provide perspectives on violence in society. Achterhuis suggests that instead of seeking the absence of violence in society, one should rather seek how to differ responsible and peaceful from one another. Violence cannot be ignored or eradicated. Violence can however be tamed by fighting with one another peacefully. Society is in need of volunteers who will act as powerful buffers between conflicting societies, thus preventing differences becoming reasons for violence.

\section{Introduction}

Perhaps an explanatory note on the title. Shylock is one of the characters in a play written by Shakespeare, The Merchant of Venice. The word Shutup is indeed a rude word. It can even be considered a violent word. When using the word Shutup!, a particular context is called to mind: a context where one party is forcefully and perhaps emotionally trying to prevent the other party from speaking. In this article, it will become clear that we as readers are screaming at Shylock to Shutup! as he is conveying information that we wish not to hear:

\begin{abstract}
Hath not a Jew eyes? Hath not a Jew hands, organs, dimensions, senses, affections, passions; fed with the same food, hurt with the same weapons, subject to the same diseases, heal'd by the same means, warm'd and cool'd by the same winter and summer as a Christian is? If you prick us, do we not bleed? If you tickle us, do we not laugh? If you poison us, do we not die? And if you wrong us, shall we not revenge? If we are like you in the rest, we will resemble you in that. If a Jew wrong a Christian, what is his humility? Revenge. If a Christian wrong a Jew, what should his sufferance be by Christian example? Why, revenge. The villainy you teach me, I will execute, and it shall go hard but I will better the instruction.
\end{abstract}

(Shylock, the Jew in The Merchant of Venice by William Shakespeare - Act III, scene I)

In this excerpt, the character, Shylock the Jew, is addressing Christians on the matter of human nature, emphasising the fact that human nature compels us to take revenge once we have been wronged. The story of The Merchant of Venice is not only a love story but also a story that portrays the tension between Christians and Jews, resembling inter-religious dissonance still witnessed today.

In short just a reflection on the plot of The Merchant of Venice: A young man from Venice, Bassanio, is in need of money to finance his planned marriage with the lady known as Portia. He asks a fellow merchant, Antonio, to lend him the money. Antonio is cash strapped and decides to borrow money for his friend from a Jewish moneylender, Shylock. The contract between Shylock and Antonio determines that the money borrowed be paid back within 3 months. Upon defaulting on payment, Shylock will be permitted to take a pound of flesh from Antonio. Literally cutting a piece from Antonio's body to the weight of one pound. All agree on the terms. Meanwhile, the fleet owned by Antonio carrying merchandise apparently sinks at sea, leaving him in debt. Simultaneously to these events, a friend of Bassanio, Lorenzo, elopes with Shylock's daughter, Jessica.

It is at this junction that we hear the speech of Shylock quoted above, addressed to two fellow merchants in Venice. The conversation takes place in front of Shylock's house. The two merchants, Solanio and Solerio, discuss the predicament of Antonio, who has lost some ships at sea. As they ask Shylock what news he has about Antonio, Shylock responds by indicating how Antonio in the past 'hath disgraced him, laughed at his losses, mocked his gains, scorned his nation (the Jews),' and the only reason for this was that Shylock was a Jew. Antonio owes Shylock money and if he is unable to pay his bond, Shylock intends taking revenge on Antonio. 
Solanio, in the absence of Shylock, describes him as the likeness of the devil (Act 3 scene 1 ) and accuses him of usury.

The due date for repayment of Antonio's debt has passed and Shylock is demanding his pound of flesh. Infuriated by Lorenzo kidnapping his daughter, Shylock vows to take revenge on the Christians he has done business with. Antonio's friends try and convince Shylock to accept double the payment of the amount Antonio owes him in exchange for the life of Antonio. In this scene (Act 4, Scene 1), we hear the plea of Bassanio appealing to the mercy of Shylock: Bassanio: 'Do all men kill the things they do not love?' upon which Shylock replies: 'Hates any man the thing he would not kill?'

Portia, Bassanio's beloved, shows up at the court where Shylock is demanding justice from Antonio. Portia, disguised as a lawyer, reminds the court of the law of Venice: no man can plan and commit the murder of a Christian, and as Shylock's right to take a pound of flesh from Antonio may cause his death, the court will have to charge Shylock with attempted murder and conspiracy to kill. The court immediately redresses the accusation and fines Shylock all his wealth for this planned murder of Antonio. Shylock's fine is to render half his wealth to the city of Venice and half to Antonio. Antonio returns his half to Shylock on two conditions: firstly, Shylock must give his regained wealth all to his daughter Jessica, who he has meanwhile disinherited. The second condition is that Shylock should immediately convert to Christianity.

Everybody celebrates at the end of the play, and everybody is happy with the outcome, except Shylock. The judicial system seems to have failed Shylock, who had presented a valid legal document which should have resulted in him being compensated for his loss. The outcome however is that Shylock now becomes the villain and is being punished. Is this the correct verdict against Shylock, or was the verdict influenced by an anti-Semitic bias?

Shylock's eloquent appeal to his audience, the famous quotation I made in the beginning, is to indicate that Jews are also human and should be treated humanely. But more importantly and relevant to our discussion, Shylock points out the fact of human nature prone to retaliation upon infliction. Violent actions beget violent responses. Perhaps, we would have preferred if Shylock did not make us aware of who we as humans are. Almost as if we would have liked to prevent Shylock from sharing this insight. As if we would have wanted to shout: 'Shutup Shylock! Do not remind us of our violent human nature!'

It becomes even more intriguing when one considers that these words of Shylock, put in the mouth of a Jew by an English Christian, William Shakespeare, were written in $1596^{1}$ in England from where Jews were banned from society

1.Scholars agree that the earliest date in which The Merchant of Venice could have been written is 1594 and the latest date is 1598. since 1290 and only permitted to return in 1656 (Tepp \& Mayer 1994:36). The courageous Shakespeare dares to include a Jewish character in a play to be performed in front of an English audience, where no Jew was permitted, leaving the audience at the end of the play with some kind of sympathy for Shylock, who has been left with nothing but his life, and at that a new life now as a Christian. Shakespeare seems to challenge the English society of his time on how religious intolerance is affecting the functioning of society.

But this is not only a discussion about Jewish and Christian relations. Talking about violence and retaliation as part of human nature is just as much a part of human existence today.

\section{Hans Achterhuis (1942)}

The Dutch philosopher Hans Achterhuis reminds us that there is not only one theory as to what violence is or to identify its origin (Achterhuis 2010b:40,44). Violence is best understood when the multiplicity of perspectives informs our understanding of it. Achterhuis utilises six perspectives illustrated by philosophy and literature to bring about a comprehensive understanding of violence. It should not be understood that Achterhuis presents an exhaustive list of perspectives on violence here. A conscious decision by Achterhuis must have guided him in limiting the list to these six perspectives. Achterhuis (2010b:24) employs the following six perspectives on violence:

\section{Goal-orientated violence}

In order to reach a goal (i.e. survival, wealth and power), humans will violently remove any obstacle (i.e. people or structures) that comes their way (Achterhuis 2010b:45). Violence becomes the means in order to reach a goal. Violence is then viewed as an instrument. This position is represented by the German-born philosopher Hannah Arendt (19061975) (Achterhuis 2010b:46). In Arendt's work Crisis in the Republic (1970), she purports that violence has become a means to several ends (Arendt 1970:145). She however emphasises that the concepts of power and violence need to be separated. Political power ensures a safe existence for society. Violence can be destructive to the good life the state is supposed to maintain. Terrorism and structural violence are discussed by Achterhuis in this category. Structures may oppress and may be necessary to remove in order to restore harmony and peace in society. Violence is then justified in terms of the good that can come from it. In order to remove oppression, violent opposition is necessary. Violence becomes the means to reach the goal of an ideal society even if violence is necessary to bring about peace.

\section{Struggle for recognition}

Humans are in need of recognition. Achterhuis (2010b:47) follows Hegel's philosophical theory to explain how two people living besides one another struggle to be recognised by the other. This struggle ends inevitably in one surrendering to the other. This serves as basis for the explanation of cultural clashes. Achterhuis applies the theory of Hegel to the violence 
between sexes (male and female) and violence against children (2010b:48).

\section{The polarity of us versus them}

In a multi-religious society (and even secular), different identities clash. Achterhuis (2010b:49) however indicates that this opposition of parties existed from antiquity. In a globalised world, people are trying to recover lost identities. Within this context, Achterhuis (2010b:49) places the occurrences of genocide. Even xenophobia can be seen as a symptom of this problem. The 'other' is considered a threat and constantly viewed with suspicion. Any negative incident is blamed on the 'other' as an evil attempt to destroy that which is considered dear. The philosopher Carl Schmitt indicates, according to Achterhuis, that the polarity of 'we and them' is inevitably part of the political reality. The solution Achterhuis (2010b:49) suggests is that different religious and ethnic groups ought to exist in one political system where the identity of the minority is accepted.

For Achterhuis (2010b:315), the most pronounced polarity between the 'us' and 'them' is portrayed in the concept of civilisations that clash as described by Samuel Huntington in his book The Clash of Civilizations (1997): 'De conflicten die op de breuklijnen van culturenzoudenontstaan, warenvolgens Huntington voor de naastetoekomst de gevaarlijkste'.

\section{Violent human nature}

Violence is not the activity of barbaric people. Hannah Arendt (2003:18) indicates how violence is committed by normal people who act on temptation to do evil. Her research on war time atrocities illustrates that normal people are capable of horrid and violent acts. Evil is not something autonomous outside of human nature. Violence is potentially present in every human being. Violence is part of human nature. Shylock's appeal to his fellow merchants emphasises exactly this: How can you not expect wronged people to respond and retaliate! Humanity has been described as being 'the naked ape' (Achterhuis 2010b:52) and more vividly as the angry primate possessing weapons (Lorenz 1966:208). Achterhuis' (2010b:52) conclusion is that through the evolution of mechanisms, human nature has ended up still being described as violent.

Religion is not the only cause of violence. '... zit het geweldevenwelniet in de religiezelf, maar in de mens. Religie kanhoogstes de lontzijn die het explosievegewelddadige materiaaldatkennelijk in de mensen de menselijkeverhoudingen self zit ...' (Achterhuis 2010b:323).

\section{Morality and politics}

Violence based on moral grounds can take on any form in politics. The American theologian-philosopher Reinhold Niebuhr (2005 [1932]) discussed the moralisation of violence. Violence in politics is morally motivated. This perspective describes the differentiation of all political actions into good or evil. Violence in service of the good against that which is considered as evil then becomes acceptable or tolerable violence. As an example, Actherhuis (2010b:50) discusses the concept of a just war. In this regard, Achterhuis investigates the thoughts of the church father Augustine. Violence is acceptable when it serves the moral good.

\section{Mimetic desire}

Based on René Girard's (1923-2015) theory (published in 1986 and 1989) that all human culture originates from mimetic desire, Achterhuis (2010b:51) indicates how conflict has always been part of human interaction. According to mimetic desire, humans want that which others possess. By mimicking the other in terms of their desire, humans end up in conflict. This creates the scarcity of things. Mimetic desire entails subjective as well as objective elements which are scarce and lead to violence in order to get hold of limited resources (Achterhuis 2010b:52). Malthus' theory (1798:4) that the increase in the world population will lead to violence based on limited resources applies here. To ventilate tension, violence is directed at the scapegoat. According to Girard (1986), the identification of the scapegoat in society is the origin of human society. Culture has a violent origin. This is betrayed by rituals and myths attesting to this. Hannah Arendt (2003:18) also attests to the violent origin of culture, nations and states.

These six perspectives are presented by Achterhuis in order to come to a better understanding of what violence is and where it comes from. This is however not an exhaustive list. The perspectives however help to get a handle on understanding current cases of violence.

To search for one cause and reason for violence is like ignoring the current weather pattern that predicts that lightning is eminent. To search for one source of violence is already to engage violently with the understanding of something so complex as violence (Achterhuis 2010b:39). There are many possible reasons for violence: class differences, poverty, social structures such as capitalism, socialism, religious fundamentalism and so on (Achterhuis 2010b:39). Violence only gets meaning the moment when all perspectives are taken into account (Achterhuis 2010b:44).

Current world conditions are conducive to violence. We live in a world characterised by the violent power of the times: 'gewelddadigegeest van die tijd' (Achterhuis 2010b:21). Similar to a threatening thunderstorm, the conditions worldwide currently are conducive for lightning to strike. It may be impossible to say where lightning will strike (2010b:26), but it is clear it will strike (Achterhuis 2010b:25). Violence is inevitable. It must however be stated that violence has always been part of human history. Achterhuis cannot reduce the interpretation of history as if violence is a current phenomenon only.

Understanding violence includes understanding oneself (Achterhuis 2010b:23). Philosophical approaches include being self-critical and attempting to think differently 
(Achterhuis 2010b:24). In the discourse on violence, philosophers have the task to identify the possible localities where lightning might strike next and to warn, prevent and, if not that, at least suggest precautious measures ('installing lightning rods') (Achterhuis 2010b:25). The book by Achterhuis has exactly this purpose in mind.

\section{The relation of violence to religion}

Regarding the relationship between religion and violence, Achterhuis once more provides some insight.

According to Achterhuis (2010b:323), religion does not lead to violence. The origin of violence does not lie within religion. The origin of violence much rather ought to be searched for within human nature. Shylock made reference to this when he pointed out how retaliation is part of human nature, that is, all humans are prone to react violently upon infliction. Violent actions can lead to violent responses. Hannah Arendt's warning that even good people can perform horrid acts of violence confirms this notion that violence is part of human nature. One act of violence can become the spark for a long chain of violent reciprocal retaliations. Examples abound: Christian-Muslim relations are today still hampered by recollections of the injustices and violence during the crusades. Christian-Jewish relations are today still influenced by accusations against Jews being the God-killers (cf. Kessler 2010:102) 2000 years ago. Violent actions can cause violent responses.

Even in the absence of religion in society, violence will still continue to exist. Religion is not a prerequisite for violence. Achterhuis (2010b:313) points out how the dichotomy of 'we' versus 'them' has created extreme cases of violence in communities all over the world since antiquity and will continue to do so. Religion is not necessarily the cause of all such instances of violence. It can however not be denied that religion can exacerbate violence. Religion can only be the fuse leading to an explosion of violence (Achterhuis 2010b:323). Religion in itself is not the cause, but religious differences can exacerbate violence. An intolerant attitude by religious practitioners towards different religions or even dissidents from inside a religion increases the likelihood of violence.

The moment when the character Solanio, in the absence of Shylock, describes Shylock as the likeness of the devil (Act 3 scene 1) and accuses him of usury, an act of violence already occurs. Creating caricatures, mocking the others and stereotyping others, these are already examples of clandestine acts of violence, begetting violent responses. Solanio uses a derogatory religious image, likening Shylock to the image of the devil. Likening others from different religions to images of evil is already committing acts of violence against them. Presenting ourselves (the 'we') as being different and superior to the other (the 'them'), the fuse setting off this eternal chain of reciprocal violence is lit.

So what is the solution? How do 'we' live in peace with the 'them'? Or stated differently, how is inter-religious tolerance possible? How do we reach the utopian condition of peace?

\section{Utopia}

Thomas More (1478-1535) wrote his treatise Utopia (1516), reflecting on social, financial, ethical, religious and political matters, pleading for equality and justice. This treatise reflected the wish of humankind for a society where peace and harmony reign in the absence of evil, pain, despair and violence.

Thomas More portrayed this idealised society as fictional, presenting the ideal as if on an island known as Utopia where religious freedom governs society and all are welcome, whether 'sun-worshippers, moon-worshippers or planetworshippers or monotheists' (1516:155). Augustine on the other hand reflected on this idealised form of existence from a Christian perspective. Long before More, Augustine (Translation by Marcus Dods, 1950) wrote about the city of God as opposed to the City of Man (the Earthly city), describing two distinct idealised places, governed by different manifests: the one a place where God reigns in peace and harmony, and the other a place where humans govern themselves and therefore delivered to seeking pleasure selfishly. The battle between the two cities is in fact a battle between good and evil.

The concept of utopia becomes descriptive of an environment where all that is considered good and beneficial to all humankind flourishes. In the second part of his treatise, $\mathrm{More}^{2}$ describes the origin of the concept of utopia as to derive from the two Greek words ou and topos, literally translated as 'no-place' or 'nowhere', indicating the illusionary and fictional character of the concept of utopia. This is as opposed to the popular understanding of utopia as an idealised, perfect place. One of the many descriptions of Utopia is the fact that the inhabitants of this island detest war (1516:140), emphasising their endeavour to limit violence.

Today, this wish to create Utopia can be seen in the efforts of religious inspired groups all over the world. As examples there are several extremist sectarian groups endeavouring to create an exclusive idealist community, separated from society, that can be mentioned. In this regard, think of Islamic State in Iraq and Syria (ISIS). ISIS is trying to establish a theocracy, a divinely governed Muslim-regulated environment, a true caliphate. In their effort to establish such a place, violence is needed to break down earthly structures of government in order to establish a new order: a utopia. Achterhuis (compare 2010b:466-469) refers to this scenario where violence becomes a means to an end; violence is needed to create something worthwhile, establishing an ideal. In this case, violence is needed in order to establish Utopia. Achterhuis $(1995 ; 1996 ; 1998 ; 2010 a ; 2016)$ also wrote extensively on the concept of utopia.

Such idealist utopian-seeking communities need not be violent. The Amish community living in Pennsylvania (US)

2. In an addendum to his book, Wherefore not Utopie, but rather rightely my name is Eutopie, a place of felicitie, More describes the confusion between the Greek outopos $=$ no place and eutopos $=$ good place. 
may serve as an example. A peaceful community is a community that lives separately from society following their own unique lifestyle, creating an idealised environment built on certain values.

As to re-creating utopia as an environment devoid of violence and injustice, Achterhuis provides an important perspective. Violence is not only religiously inspired. As indicated earlier, the origin of violence is much rather to be discovered within human nature, as Shylock so eloquently stated. So wherever humans are, the potential for violence exists. Achterhuis suggests that true utopia, the absence of violence, will remain an illusion and a fiction. Instead of seeking the origin of violence in order to stem it or establishing the absence of violence (utopia), rather learn how to fight and differ well. This notion Achterhuis (2014) develops in his aptly named publication De kunst van vreedzaamvechten [the art of fighting peacefully].

For Achterhuis (2014:17), a world devoid of violence is not only inconceivable but also undesirable. To have conflicting ideas is considered a valuable characteristic of an open society. Views from different perspectives work towards creatively and innovatively solving social problems. If different views exist in society, it should not be seen as a threat, but rather as a characteristic of a successful democratic society where everyone's opinion is considered. Diversity then is not a sign of animosity and discord, but a sign of openness and inclusivity. The art is how to prevent differences from becoming reasons for violence.

Achterhuis (2014:26) admits that society will need several voluntary change agents and leaders who act as powerful buffers between conflicting groups in society in order to prevent violence from erupting, as the threat of real or perceived violence can lead to retaliation, as Shylock earlier described human nature. Such volunteers in society play an important peacekeeping role, many times under-valued and unappreciated: 'Ze speleneenmeestalonderschattegezveldbeteuge lenderolengebruikendaarbijmeer of minder effectieveverleidings strategieën' (Achterhuis 2014:26). To differ is not a transgression. But to express differences in violent forms is an act of selfish self-realisation.

Achterhuis mentions several institutions assisting society in limiting occasions of violence. The democratic judiciary state becomes the greatest weapon against violence. Democracy, the judicial system and also sport become fields where people experience gain and loss and realise that such victories and losses take place on specific, limited fields.

The problem however is that Shylock becomes a victim of an unjust judicial system. In this instance, Achterhuis' suggestion that the democratic judiciary state should protect people from such subtle forms of violence fails. In order to ensure a just judiciary system, the laws governing society need to be constantly scrutinised in order to ensure that laws do not protect and serve the rights of only one segment of society, but that all members of society can expect to receive fair treatment by the law in order to bring about peace and reconciliation.

On the matter of justice and reconciliation, Achterhuis (2010c:23) indicates that justice is not only about philosophical theory and religious doctrine but also about the practical matter of forgiveness and continuing with life after injustice has been experienced and dealt with appropriately.

It is interesting that the event halting violence in The Merchant of Venice was not the plea by Antonio's friends for his life, begging and appealing to Shylock to show mercy, neither was it the over-compensation Antonio's friends offered Shylock. The friends offered Shylock three times the amount of money Antonio owed him in order to save his life. Shylock did not budge. The only event stemming violence was the law. Only when Portia indicated that the judicial system of Venice does not permit conspiracy and planning of murder, Shylock had to let go of his violent plan. The judicial system seems to have the biggest effect on potential violent events. To appeal to human nature to show mercy and forgiveness does not seem to have effect. But because everybody is subject to the law, this will stem violence. The condition as pointed out in the previous paragraph remains that the laws governing society need to be critically evaluated and adjusted if necessary in order to serve justice to all in society.

Even if Achterhuis does suggest practical advice on how to prevent violence, we realise this already is an attempt at creating utopia. Whether it will be an attempt with realistic peaceful results needs to be seen.

\section{Conclusion}

Back to the beginning. We started off with a strange title: Shutup Shylock. What is it that we do not want to listen to in Shylock's words? Perhaps Shylock reminds us of the equality and the humanity of all human beings. Equality: By asking a rhetorical question, Shylock is trying to indicate to his audience that Jews are just as much human as every other human being. For him, humans are equal and should be treated accordingly. Religion cannot be a reason to discriminate and even hate others.

But Shylock is also reminding us of a human trait that we perhaps do not want to be reminded of. Humans carry inside of them the potential to act violently and also to reciprocate with violence: retaliation. This is a human characteristic which applies to all humans no matter what religion they belong to. Equality and the potential to act and respond violently are perhaps ideas we wish not to hear, therefore the plea for Shylock to keep quiet.

Shylock is indeed a fictional character, true. But this does not mean that his words are less true. Reality around us is a proof that violence is as apparent as expecting lightning from thunderstorm clouds. People from different religious convictions tend to orchestrate violence against others, 
motivated by religious differences. In a multi-religious society, the close proximity of people from different religions struggling to attain limited resources for survival provide conditions conducive to inter-religious violence. Shylock does not have a pleasant message: violence and retaliation are part of human nature and can be expected. That is why we want him to keep quiet. But perhaps he should not keep quiet, but instead keep on reminding us of the reality of violence.

\section{Acknowledgements Competing interests}

The author declares that he has no financial or personal relationships which may have inappropriately influenced him in writing this article.

\section{References}

Achterhuis, H., 1995, De utopieenhaarverschijningsvorm, Lumiance Lecture, Amsterdam.

Acterhuis, H., 1996, 'La responsibilitatrailtimore e l'utopie', in G. Hottius \& M.G. Pinsart (eds.), Hans Jonas: Natura e responsibilita, pp. 99-110, Edizione Millela, Lecce, Italie.

Achterhuis, H., 1998, De erfenis van de utopie, Ambo, Baarn.
Achterhuis, H., 2010a, De utopie van de vrijemarkt, Lemniscaat, Rotterdam.

Achterhuis, H., 2010b, Met allegeweld: Eenfilosofischezoektocht, Lemniscaat, Rotterdam.

Achterhuis, H., 2010c, 'Peace and justice: On the dilemmas of negotiations', Pax Christi, viewed 24 July 2018, from https://www.paxchristi.net/sites/default/files/ documents/2010-0197-en-gl-JW.pdf

Achterhuis, H., 2014, De kunst van het vreedzaamvechten: Eenzoektochtnaar de bronnen van geweldbeteugeling, Lemniscaat, Rotterdam.

Achterhuis, H., 2016, Koning van Utopia, Lemniscaat, Rotterdam.

Arendt, H., 1970, Crises of the Republic, Lane Publishers, London.

Arendt, H., 2003, Responsibility and judgment, Schocken Books, New York.

Augustine, 1950, The city of God, transl. M. Dods, The Modern Library, a division of Random House, New York.

Girard, R., 1986 [1982], The scapegoat, transl. Y. Freccero, Johns Hopkins University Press, Baltimore, MD.

Girard, R., 1989 [1972], Violence and the sacred, transl. P. Gregory, Johns Hopkins University Press, Baltimore, MD.

Huntington, S., 1997, The clash of civilizations, Simon \& Schuster, New York.

Kessler, E., 2010, An introduction to Jewish-Christian relations, Cambridge University Press, New York.

Lorenz, K., 1966, On aggression, Methuen and Co. Ltd., London.

Malthus, T., 1798, An essay on the principle of population, Printed for J. Johnson, in St. Paul's Church-Yard, London, viewed 14 August 2017, from http://www.esp.org/ books/malthus/population/malthus.pdf

More, T., 1516, Utopia, viewed 21 August 2017, from www.planetpdf.com/planetpdf/ pdfs/free_ebooks/Utopia_NT.pdf

Niebuhr, R., 2005 (1932), Moral man and immoral society, Continuum, New York.

Tepp, L. \& Mayer, G., 1994, 'Geschichte des nachbiblischenJudentums in Grundzügen', in G. Mayer (ed.), Das Judentum, pp. 17-72, Verlag W. Kohlhammer, Stutgart. 